\title{
Seroprevalence of Toxoplasma gondii in Dairy Cattle with Reproductive Problems in Sudan
}

\author{
Abdelghafar M. Elfahal, ${ }^{1}$ Amira M. Elhassan, ${ }^{2}$ Mohammed O. Hussien, \\ Khalid A. Enan, ${ }^{1}$ Azza B. Musa, ${ }^{1}$ and Abdelrahim M. El Hussein ${ }^{3}$ \\ ${ }^{1}$ Central Laboratory, Ministry of Science and Technology, P.O. Box 7099, Khartoum, Sudan \\ ${ }^{2}$ Veterinary Research Institute, P.O. Box 8067, Khartoum, Sudan \\ ${ }^{3}$ Animal Resources, Research Corporation, P.O. Box 8067, Khartoum, Sudan
}

Correspondence should be addressed to Abdelghafar M. Elfahal; ghafra45@gmail.com

Received 4 July 2013; Accepted 21 August 2013

Academic Editors: A. Berman and Z. Grabarevic

Copyright (C) 2013 Abdelghafar M. Elfahal et al. This is an open access article distributed under the Creative Commons Attribution License, which permits unrestricted use, distribution, and reproduction in any medium, provided the original work is properly cited.

\begin{abstract}
Toxoplasmosis, caused by Toxoplasma gondii, is one of the most common parasitic infections of humans and other warm-blooded animals in most parts of the world. The disease is common among sheep and goats and it is recognized as one of the major causes of reproductive failure in these animals. Cattle, on the other hand, can be infected, but abortion or perinatal mortality has not been recorded. This survey was carried out to study the prevalence of this disease in cattle in Khartoum and Gazira States (Sudan). 181 sera samples collected from dairy cattle with reproductive problems were assayed for antibodies to T. gondii by ELISA. The prevalence rate of $T$. gondii antibodies in cattle at herd level was $44.8 \%(13 / 29)$. Herd level infection rates were $50 \%$ and $33.3 \%$ in Khartoum and Gazira States, respectively. The overall prevalence of T. gondii at individual level in both states was 13.3\% (24/181). The prevalence was $12.7 \%$ (17/134), was 14.9\% (7/47) in Khartoum and Gazira State, respectively. There was significantly higher $(P<0.05)$ prevalence of $T$. gondii antibodies in the age group less than one year old $(36.4 \%)$ than in other age groups and in males $(30.8 \%)$ than in females (11.9\%) while no significant relationship was discerned regarding breed, location, season, or signs of reproductive disease.
\end{abstract}

\section{Introduction}

Toxoplasmosis is one of the most common human parasitic infections worldwide with an estimated prevalence in 1-2 billion people [1]. Toxoplasmosis is a zoonotic disease caused by a sporozoan parasite, Toxoplasma gondii, distributed throughout the world. The definitive hosts are domestic cats and various species of wild felids and the intermediate hosts are mammals and birds [2].

Transmission occurs following ingestion of sporulated oocysts or bradyzoites within cysts present in the tissues of numerous food animals. The frequency of infection is extremely variable in the different regions of the world. Seroprevalence in the human population reportedly ranges from 0 to $90 \%$ [3] and infection is more common in warm climates and in low-lying areas than in cold climates and mountainous regions, where conditions for sporulation and survival of oocysts are less favourable [4]. The prevalence of T. gondii infection also varies between ethnic groups, and it is thought that this is largely due to sanitary and cooking habits rather than genetic differences. A seroprevalence of $80 \%$ has been reported from Paris where undercooked meat is often consumed [4]. Lower seroprevalences (10-40\%) have been reported in countries from Southeast Asia where meat is cooked thoroughly [5].

There is limited evidence supporting the hypothesis that cattle are not a favoured host for $T$. gondii but in general infection is more likely to occur from consumption of pork, lamb's and goat's meat than from beef [6-8] and consumption of cured pork has indeed been recognized as an important source of T. gondii infection [9].

Limited information is available on the prevalence of toxoplasmosis in man and animals in Sudan. Camel toxoplasmosis was first reported in Sudan by El Din et al. [10] who 
TABLE 1: Herd level prevalence of T. gondii antibodies in cattle in Khartoum and Gazira States detected by ELISA.

\begin{tabular}{|c|c|c|c|c|c|}
\hline Area & Location & No. of herds & Total no. of animals & +ve herds & $+\mathrm{ve} \%$ \\
\hline \multirow{3}{*}{ Khartoum } & Khartoum & 8 & 240 & 4 & 50 \\
\hline & Khartoum North & 7 & 250 & 4 & 57.1 \\
\hline & Omdurman & 5 & 210 & 2 & 40 \\
\hline Subtotal & & 20 & & 10 & $50 \%$ \\
\hline \multirow{2}{*}{ Gazira } & Alkamleen & 1 & 30 & 1 & 100 \\
\hline & Wad Madani & 8 & 370 & 2 & 25 \\
\hline Subtotal & & 9 & & 3 & 33.3 \\
\hline Total & & 29 & 1100 & 13 & 44.8 \\
\hline
\end{tabular}

recorded an infection rate of 54\%. Afterwards Bornstein and Musa [11] and Elamin et al. [12] reported $22.5 \%$ and $11.8 \%$ in Sudanese camels, respectively. A more recent study recorded prevalence rates of toxoplasma antibodies of $20 \%, 32 \%$, and $57.5 \%$ in camels, cattle, and sheep, respectively [13]. Prevalence rates of up to $73 \%$ were recorded in childbearing age women and up to $100 \%$ in camel herders in Sudan [14-17].

The present study was carried out to assay seroprevalence of T. gondii in dairy cattle herds with reproductive problems and to determine risk factors associated with the infection in two states, namely, Khartoum and Gazira of Sudan.

\section{Materials and Methods}

A total of 181 (168 females and 13 males) serum samples were taken from dairy cattle herds with reproductive problems such as abortion, infertility, and stillbirth. Dairy herds were raised under semi-intensive husbandry systems in farms around Khartoum State (Khartoum, Khartoum North, and Omdurman) and Gazira States (Al Kamleen and Wad Madani). Blood was collected from cattle by vein puncture of the jugular vein. Sera were harvested following centrifugation of clotted blood, labeled, and stored at $-20^{\circ} \mathrm{C}$ until tested. Antibodies to T. gondii were tested by indirect enzyme linked imunosorbent assay (iELISA). A herd was considered positive for T. gondii when at least one animal with positive antibody reaction was detected.

2.1. ELISA Technique. Commercial iELISA kits (Ruminant Serum Toxoplasmosis) for detection of anti-T. gondii antibodies were purchased from Lsivet (Nouzilly, France). Positive serum samples will present yellow colour; the colour visualized in each well is proportional to the titer of antibody specific to $T$. gondii present in the diluted sample (1/400). All samples which have antibody titer $\geq 20$ are considered positive.

2.2. Statistical Analysis. The serological results and other information gathered during this investigation such as season, location, breed, sex, and age of the sampled animals were edited and analyzed statistically using statistical package (SPSS version 13). To identify the association of the risk factors with the specific seroprevalence, the chi-square $\left(\chi^{2}\right.$ test) and one-way ANOVA were used. The statistical significance level used was $P \leq 0.05$.
TABLE 2: Seropositivity to T. gondii in cattle from different locations in Khartoum State and Gazira State detected by ELISA.

\begin{tabular}{lcccc}
\hline Area & Location & No. tested & Positive & Positive \% \\
\hline \multirow{2}{*}{ Khartoum } & Khartoum & 62 & 8 & 12.9 \\
& Khartoum North & 43 & 6 & 14 \\
\multirow{2}{*}{ Subtotal } & Omdurman & 29 & 3 & 10.3 \\
\hline \multirow{2}{*}{ Gazira } & & 134 & 17 & 12.7 \\
Subtotal & Alkamleen & 8 & 2 & 25 \\
Total & Wad Madani & 39 & 5 & 12.8 \\
\hline
\end{tabular}

\section{Results}

3.1. Herd Infection Level. Out of 29 herds tested at both states, $13(44.8 \%)$ proved to be positive for $T$. gondii antibodies by ELISA. The result showed that 10 (50\%) out of the 20 herds in Khartoum State and 3 (33.3\%) out of nine herds in Gazira State were positive with the highest herd prevalence $(57.1 \%)$ being detected in Khartoum North locality (Khartoum State) (Table 1).

3.2. Individual Infection Level. One hundred and eighty one serum samples from Khartoum and Gazira States were assayed for the presence of anti-Toxoplasma gondii antibodies using ELISA. The overall prevalence of T. gondii in both states was $13.3 \%$ (24/181). The prevalence rate was $12.7 \%(17 / 134)$ in Khartoum State and the prevalence according to the locality was as follows: $12.9 \%(8 / 62), 14 \%(6 / 43)$, and $10.3 \%(3 / 29)$ were recorded for Khartoum, Khartoum North and Omdurman localities, respectively. In Gazira State the prevalence rate was $14.9 \%(7 / 47)$ and positive samples were detected in Alkamleen 25\% (2/8) and Wad Madani 12.8\% (5/39) localities (Table 2).

The prevalence of $T$. gondii infection was significantly $(P<0.05)$ higher $(36.4 \%)$ in animals less than one year old than those above two years (12.8\%). Moreover, significantly $(P<0.05)$ higher seroprevalence of $T$. gondii was observed in males $(30.8 \%)$ than in females $(11.9 \%)$, but there was no significant relationship between antibodies prevalence and breed, location, season, or signs of reproductive disease (Table 3). 
TABLE 3: Influence of some risk factors on seroprevalence of T. gondii in cattle using ELISA in Khartoum and Gazira States.

\begin{tabular}{|c|c|c|c|c|}
\hline Variable & Groups & No. tested & Positive & Positive $\%$ \\
\hline \multirow{3}{*}{ Age (year) } & $<1$ & 11 & 4 & $36.4^{*}$ \\
\hline & $1-2$ & 14 & 0 & 0.00 \\
\hline & $>2$ & 156 & 20 & 12.8 \\
\hline \multirow{2}{*}{ Sex } & Male & 13 & 4 & $30.8^{*}$ \\
\hline & Female & 168 & 20 & 11.9 \\
\hline \multirow{2}{*}{ Breed } & Cross & 175 & 23 & 13.1 \\
\hline & Local & 6 & 1 & 16.7 \\
\hline \multirow{3}{*}{ Location } & Khartoum & 134 & 17 & 12.7 \\
\hline & Gazira & 47 & 7 & 14.9 \\
\hline & Winter & 90 & 11 & 12.2 \\
\hline \multirow[t]{3}{*}{ Seasons } & Dry & 26 & 6 & 23.1 \\
\hline & Rainy & 65 & 7 & 10.8 \\
\hline & $\begin{array}{l}\text { Apparently } \\
\text { healthy }\end{array}$ & 75 & 9 & 12.0 \\
\hline \multirow[t]{3}{*}{ Health status } & Abortion & 63 & 12 & 19.0 \\
\hline & Infertility & 27 & 1 & 3.7 \\
\hline & $\begin{array}{l}\text { Death of calf } \\
\text { after birth }\end{array}$ & 16 & 2 & 12.5 \\
\hline
\end{tabular}

${ }^{*}$ Significant $(P \leq 0.05)$.

\section{Discussion}

Until now insufficient data are available on cattle toxoplasmosis in the world, and there have been limited number of reports on cattle toxoplasmosis from Sudan. The overall seroprevalence of toxoplasmosis reported in the present study in Sudan using ELISA (13.3\%) is higher than that reported for cattle in China (2.3\%) [18] and Vietnam (10.5\%) [19] but is comparable to that reported in Iran (15.91\%) [2] and lower than that $(27.9 \%)$ recorded in The Netherlands [20]. The differences in prevalence rates between countries may be due to the samples size of different studies besides the different techniques used. However, data on the seroprevalence in cattle show great variation, ranging from 0 to $99 \%$ [21, 22]; hence, such data should be analyzed with caution as geographical variations occur not only among different countries but also within countries.

In the present study $T$. gondii antibodies were prevalent both at herd and at individual animal levels. Out of the 20 herds tested in Khartoum State, nine (45\%) herds proved to be positive for T. gondii antibodies and three $(33.3 \%)$ of nine herds in Gazira State were positive. The highest infection rate (57.1\%) among herds was observed in Khartoum North in Khartoum State. Although no statistically significant association was found regarding signs of reproductive disease, this high prevalence rate (four herds out of seven were infected) is in concordance with high abortion rates reported from farms in this particular area.

The seroprevalence of $T$. gondii infection reported in the current study in Khartoum State was 13.3\% using ELISA. Khalil and Intisar [13] reported that the prevalence rate of anti-T. gondii antibodies in cattle in Khartoum State using latex agglutination test (LAT) was 32\%. The difference in the prevalences between the two studies could be attributed to the different techniques used in estimating these prevalences and to the lower number (50) of cattle investigated by Khalil and Intisar [13]. Positive cases were more frequent among cattle less than one year old $(36.4 \%, P<0.05)$ than cattle above two years old. This is in concordance with Nematollahi and Moghddam [2] who reported similar results in Iran in 2008. This may reflect dominance of maternally acquired antibodies in this age group or that the cattle unless reinfected, deplete antibodies as their age increases [3]. Cattle are generally described as insensitive to $T$. gondii infection. Cattle would harbour few parasite tissue cysts, which may not persist for the lifetime of the host [23-25].

The prevalence was also observed to be significantly $(P \leq$ $0.05)$ higher in males $(30.8 \%)$ than females. Similar results were obtained by Nematollahi and Moghddam [2]. However, the numbers of males assayed for T. gondii antibodies in the present study were too low (13) to allow for any concrete conclusions regarding association of gender with the seroprevalence of this parasite.

It could be concluded that toxoplasmosis is prevalent in dairy herds in Khartoum and Gazira States. Age and gender were observed to be the main risk factors involved, while no association with signs of reproductive disease such as abortion, stillbirth, and infertility was discerned. The results also suggest that toxoplasma oocysts and reservoir host are widely distributed in the environment. Hence, further epizootiological and parasitological investigations on toxoplasmosis in cattle and other farm animals and human at the country level are required to determine the magnitude of the infection and to estimate its economic impact; the relative importance of different species in the epidemiology of toxoplasmosis; and its public health hazard in Sudan.

\section{References}

[1] H. R. Chang, "The potential role of azithromycin in the treatment or prophylaxis of toxoplasmosis," International Journal of STD and AIDS, vol. 7, no. 1, pp. 18-22, 1996.

[2] A. Nematollahi and G. Moghddam, "Survey on seroprevalence of anti-Toxoplasma gondii antibodies in cattle in Tabriz (Iran) by IFAT," American Journal of Animal and Veterinary Sciences, vol. 3, no. 1, pp. 40-42, 2008.

[3] J. P. Deuby and C. P. Beattie, Toxoplasmosis of Animals and Man, CRC Press, Boca Raton, Fla, USA, 1988.

[4] G. Desmonts, "Sérologie de la toxoplasmose," Annales de Biologie Clinique, vol. 19, pp. 13-28, 1961.

[5] P. Zuber and P. Jaquier, "Epidémiologie de la toxoplasmose situation au niveau mondial," Schweizerische Medizinische Wochenchrift, vol. 125, pp. 19S-22S, 1995.

[6] J. P. Dubey, "Persistence of encysted Toxoplasma gondii in caprine livers and public health significance of toxoplasmosis in goats," Journal of the American Veterinary Medical Association, vol. 177, no. 12, pp. 1203-1207, 1980.

[7] J. P. Dubey, "A review of toxoplasmosis in cattle," Veterinary Parasitology, vol. 22, no. 3-4, pp. 177-202, 1986.

[8] J. P. Dubey and A. Towle, Toxoplasmosis in Sheep: A Review and Annotated Bibliography, Miscellaneous Publications No. 10, The Commonwealth Institute of Parasitology, 1986. 
[9] W. Buffolano, R. E. Gilbert, F. J. Holland, D. Fratta, F. Palumbo, and A. E. Ades, "Risk factors for recent toxoplasma infection in pregnant women in Naples," Epidemiology and Infection, vol. 116, no. 3, pp. 347-351, 1996.

[10] E. A. EL Din, S. E. EL Khawad, and H. S. Kheir, "A serological survey for Toxoplasma antibodies in camels (Camelus dromedarius) in the Sudan," Revue d'ÉLevage et de Médecine Vétérinaire des Pays Tropicaux, vol. 38, pp. 257-249, 1985.

[11] S. Bornstein and B. E. Musa, "Prevalence of antibodies to some viral pathogens, Brucella abortus and Toxoplasma gondii in serum from camels (Camelus dromedarius) in Sudan," Journal of Veterinary Medicine B, vol. 34, no. 5, pp. 364-370, 1987.

[12] E. A. Elamin, S. Elias, A. Daugschies, and M. Rommel, "Prevalence of Toxoplasma gondii antibodies in pastoral camels (Camelus dromedarius) in the Butana plains, mid-Eastern Sudan," Veterinary Parasitology, vol. 43, no. 3-4, pp. 171-175, 1992.

[13] M. K. Khalil and E. Intisar, "Seroprevalence of Toxoplasma gondii antibodies in farm animals (camels, cattle, and sheep) in Sudan," Journal of Veterinary Medicine and Animal Health, vol. 3, pp. 36-39, 2011.

[14] A. A. Abdel-Hameed, "Sero-epidemiology of toxoplasmosis in Gezira, Sudan," Journal of Tropical Medicine and Hygiene, vol. 94, no. 5, pp. 329-332, 1991.

[15] A. Elnahas, A. S. Gerais, M. I. Elbashir, E. S. Eldien, and I. Adam, "Toxoplasmosis in pregnant Sudanese women," Saudi Medical Journal, vol. 24, no. 8, pp. 868-870, 2003.

[16] M. K. Khalil, A. Al-Aziz, and E. Intisar, "Prevalence of Toxoplasma gondii antibodies in camels and their herders in three ecologically different areas in Sudan," Journal of Camel Practice and Research, vol. 13, pp. 12-15, 2007.

[17] M. Khalil, K. Petr, B. Alia et al., "Imuno-diagnosis of latent toxoplasmosis in childbearing age women in rural areas in El Geizera State, Sudan," International Journal of Medical Sciences, vol. 1, pp. 272-277, 2009.

[18] J. Yu, Z. Xia, Q. Liu, J. Liu, J. Ding, and W. Zhang, "Seroepidemiology of Neospora caninum and Toxoplasma gondii in cattle and water buffaloes (Bubalus bubalis) in the People's Republic of China," Veterinary Parasitology, vol. 143, no. 1, pp. 79-85, 2007.

[19] L. T. T. Huong, B.-L. Ljungström, A. Uggla, and C. Björkman, "Prevalence of antibodies to Neospora caninum and Toxoplasma gondii in cattle and water buffaloes in southern Vietnam," Veterinary Parasitology, vol. 75, no. 1, pp. 53-57, 1998.

[20] F. van Knapen, A. F. Kremers, J. H. Franchimont, and U. Narucka, "Prevalence of antibodies to Toxoplasma gondii in cattle and swine in The Netherlands: towards an integrated control of livestock production," The Veterinary Quarterly, vol. 17, no. 3, pp. 87-91, 1995.

[21] A. M. Tenter, A. R. Heckeroth, and L. M. Weiss, "Toxoplasma gondii: from animals to humans," International Journal for Parasitology, vol. 30, no. 12-13, pp. 1217-1258, 2000.

[22] S. M. Hall, M. Ryan, and D. Buxton, "Epidemiology," in Toxoplasmosis: A Comprehensive Clinical Guide, D. H. M. Joynson and T. G. Wreghitt, Eds., pp. 58-124, Cambridge University Press, Cambridge, UK, 2001.

[23] I. Esteban-Redondo, S. W. Maley, K. Thomson et al., "Detection of $T$. gondii in tissues of sheep and cattle following oral infection," Veterinary Parasitology, vol. 86, no. 3, pp. 155-171, 1999.

[24] J. P. Dubey and P. Thulliez, "Persistence of tissue cysts in edible tissues of cattle fed Toxoplasma gondii oocysts," American Journal of Veterinary Research, vol. 54, no. 2, pp. 270-273, 1993.
[25] J. P. Dubey, G. Desmonts, C. McDonald, and K. W. Walls, "Serologic evaluation of cattle inoculated with Toxoplasma gondii: comparison of Sabin-Feldman dye test and other agglutination tests," American Journal of Veterinary Research, vol. 46, no. 5, pp. 1085-1088, 1985. 

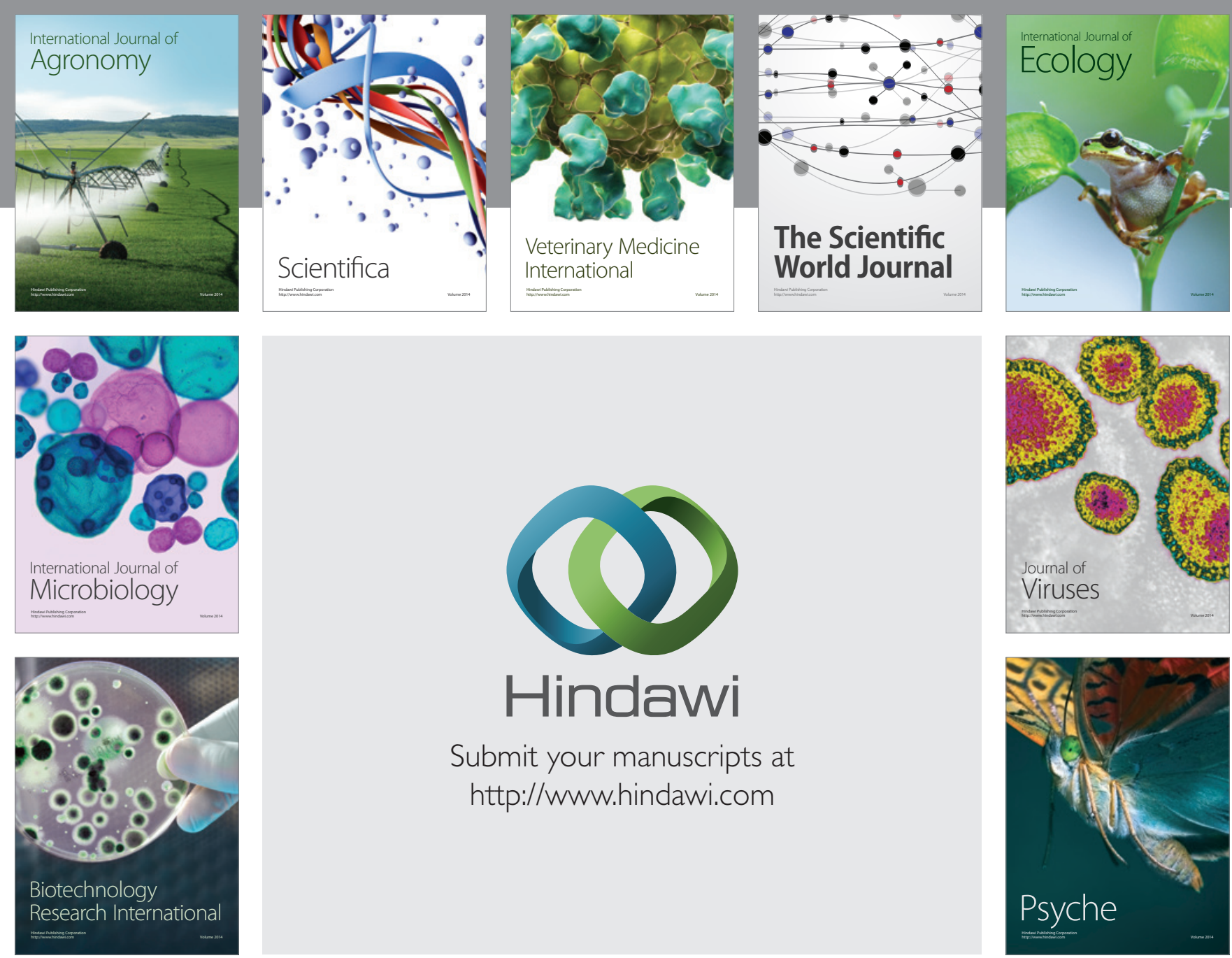

Submit your manuscripts at http://www.hindawi.com
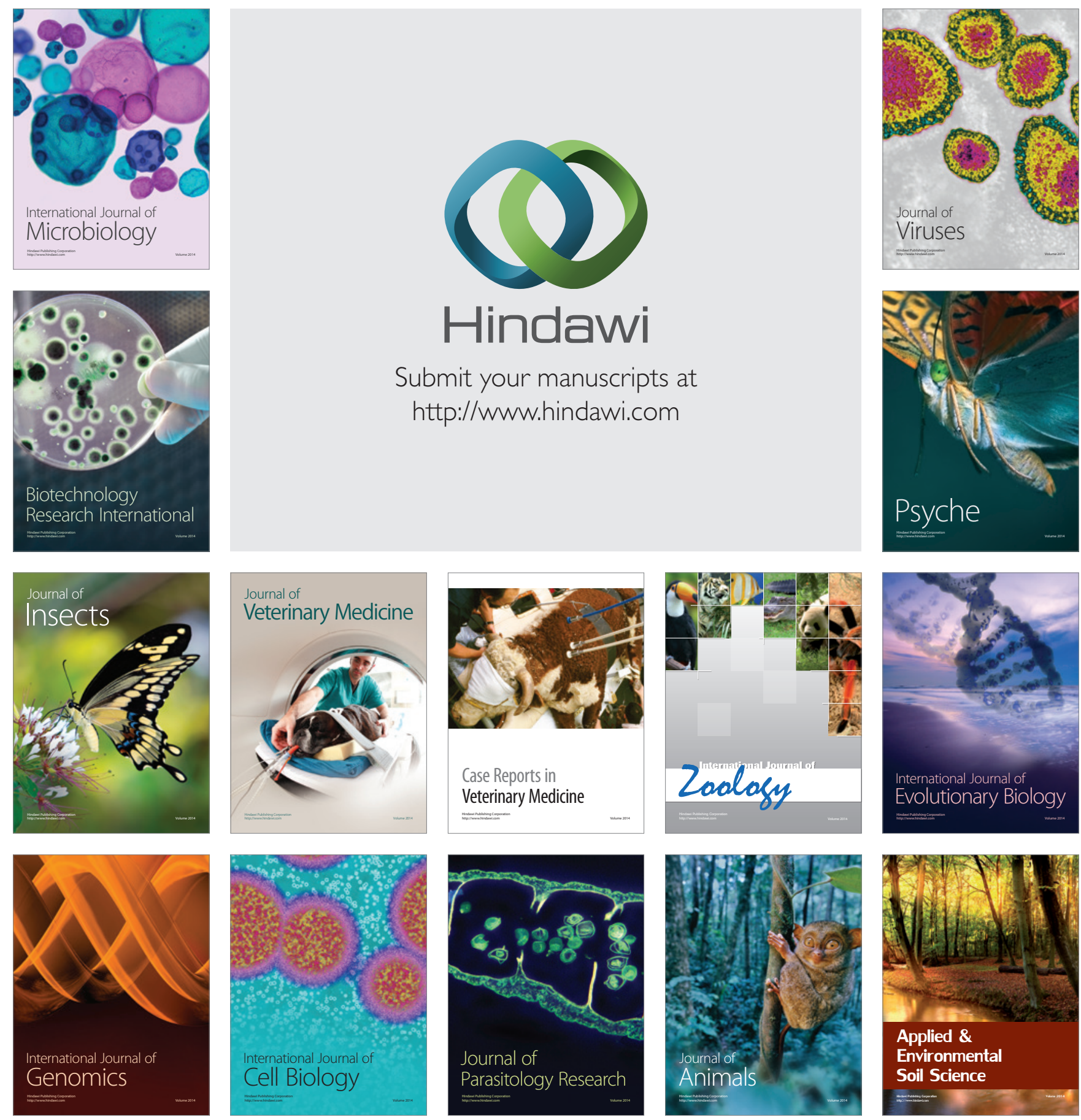